\begin{abstract}
Prostitution has been high on the French political agenda since the late 1990s, but the way in which it has been framed as a policy issue has undergone a radical change since the elections of 2002. This article compares competing definitions of prostitution as a political issue under the Jospin (1997-2002) and the Raffarin (2002-) governments. It examines the abolitionist lobby, which dominated the debates under Jospin, joining forces with women's policy agencies to place prostitution on the policy agenda as a form of violence towards women. It discusses the changes in prostitution policy since 2002, focusing on the criminalisation of soliciting and the construction of prostitutes as partvictim, part-criminal. It argues that the reframing of prostitution as a law and order issue has harsh consequences for the women in prostitution, but particularly for migrant women, who can be deported for the new offence of passive soliciting.
\end{abstract}

\title{
Prostitution Debates in France
}

\section{Gill Allwood}

Prostitution has been high on the French political agenda since the late 1990s, but the way in which it has been framed as a policy issue has undergone a radical change since the elections of 2002. Under the Jospin (1997-2002) government, prostitution debates were polarised: abolitionists, who formed a powerful coalition with access to policymakers, in particular state feminists, perceived prostitutes as victims who needed to be saved; sex workers’ rights’ advocates called for better living and working conditions for those in prostitution. Relations between the two sides were hostile. In 2002, however, the newly elected rightwing government reframed prostitution as a law and order issue, including it in the security discourse, which dominated its election manifesto. This article traces these debates, asking how the various actors involved have framed prostitution as a political issue, how prostitutes have been constructed within these frames, and what implications this has for the women concerned. It argues that the consequences of the new law are harsh, in particular for migrant women, who can be deported for the newly created serious offence of passive soliciting. 


\section{Prostitution Debates 1997-2002}

Prostitution rose up the political agenda in the late 1990s as the result of a number of factors, including international and European measures focused in particular on trafficking, child prostitution and child pornography, and transnational organised crime; a growing awareness of the presence of East European and African prostitutes, ${ }^{1}$ some of whom appeared very young; and the initiatives of women’s policy agencies, which combined with powerful abolitionist lobbies to influence the policy agenda and stimulate public debate. ${ }^{2}$ In 1999, the newly created Delegation for women's rights in the Senate decided to focus on prostitution as its first subject of enquiry. It produced a detailed and critical report on prostitution and public policy, arguing that France's official policy of abolitionism was inadequately implemented. ${ }^{3}$ French policy on prostitution firstly condemns all forms of exploitation of prostitution (living off immoral earnings, pimping, brothel owning, renting rooms to prostitutes) - but not prostitution itself, which is a civil liberty. Secondly, it supports what it defines as the 'victims' of prostitution, the prostitutes themselves, by helping them to escape from it. And it is this second pillar, the social provisions for prostitutes who want to leave prostitution, that was particularly harshly criticised by the Senate's Delegation for women's rights, which argued that the state has neglected its responsibilities in this area, leaving it to associations to step in as service providers.

The official state policy of abolitionism was adopted in 1960 with the ratification by France of the 1949 UN Convention on the Suppression of the Traffic in Persons. Until 1946, when it closed its state controlled brothels (maisons closes), France had been regulationist, and between 1946 and 1960, it maintained police files on prostitutes. The foundations of state abolitionism were laid in a series of policy measures in the early 1960s, but for most of the following thirty years, implementation varied locally, and prostitution rarely appeared on the political agenda. The exceptions were a brief mobilisation of prostitutes’ rights’ groups against police harassment in 1975 and debates surrounding a suggestion in 1990 by the former Minister for Health (1986-8), Michèle Barzach (RPR), that state brothels be reopened in order to reduce the risks to public health associated with unregulated prostitution. ${ }^{4}$ 
A series of international assertions of the French position on prostitution were made in the late 1990s, in the context of pressure by some countries and international organisations (notably the Netherlands ${ }^{5}$ and the International Labour Organisation ${ }^{6}$ ) to recognise prostitution as a legitimate occupation and prostitutes as sex workers. Foreign Minister, Hubert Védrine, reaffirmed the French commitment to abolitionism in various international negotiations on trafficking and child prostitution and pornography ${ }^{7}$; and Minister for Women’s Rights, Nicole Péry, included prostitution in her department’s high-profile campaign against violence towards women, naming it as a form of violence at the UN Beijing +5 Conference in New York in $2000 .{ }^{8}$ In these statements, France reaffirmed its commitment to the 1949 Convention which states that 'prostitution and the accompanying evil of the traffic in persons' are 'incompatible with the dignity and worth of the human person' and condemns any person who exploits the prostitution of another with or without their consent. In March 2001, Christine Lazerge, Vice President of the National Assembly, launched an enquiry into forms of modern slavery, much of which focused on prostitution. The ensuing bill was passed unanimously by the National Assembly in January 2002 but not read in the Senate before the end of the parliamentary session. It confirmed the view of prostitution as a form of violence and exploitation and of prostitutes as unconditional victims, who should be saved by the state. ${ }^{9}$ Such a position rejects the distinction between forced and voluntary prostitution that some vocal participants in international policy making were trying to legitimise.

The distinction between free and forced prostitution was integrated into Dutch public policy debates as early as the mid-1980s ${ }^{10}$ and is defended on the grounds that it will improve the living and working conditions of prostitutes and that it will strengthen the fight against transnational organised crime and in particular the trafficking of women and children. As well as embedding the distinction in national policies, the Netherlands has pushed for its inclusion in international treaties and conventions. The UN Declaration on the Elimination of Violence towards Women (1993); the Beijing Platform for Action (1995); the Council of Europe Recommendation ${ }^{11}$ on the traffic in women and forced prostitution in Council member states; and the European Parliament Resolution of 19 
May 2000 all refer to 'forced' prostitution, thus implying that there can be a voluntary kind. The report by the International Labour Office in 1998 further reinforced the notion that voluntary prostitution should be considered a legitimate economic activity. Within France, the community health group Cabiria also supports the distinction between free and forced prostitution. They argue that prostitution is not an inherent violation of human rights, as abolitionists maintain, and that it is the working conditions of some prostitutes (non-consent, exploitation), which should be condemned, not the sale of sexual services itself. They state that 'it is not the activity as such, but the conditions in which the activity takes place, that make it a violation of human rights' ${ }^{12}$

The framing of all prostitution as an inherent act of violence and violation of human rights has a tendency to construct prostitutes as victims who need to be saved and reintegrated into society. This can deny them subjecthood and agency. At a high-profile conference at UNESCO in Paris in 2000, organised by the abolitionist NGO, la Fondation Scelles, Phillippe Scelles, for example, declared, 'Prostitution is not an expression of women's freedom, but of their profound misery, the tragedy of destiny, a descent into hell. ${ }^{13}$ In Le Livre noir, prostitution is portrayed as ' $[\ldots]$ the alienation and destruction of women, men and children reduced to the state of sexual objects, of commodities in a global market, an attack on the integrity and the dignity of the human being, a negation and violation of human rights, neither "inevitable" nor a "necessary evil”, ${ }^{14}$ In this view, the victims of prostitution are usually unaware of their own oppression and alienation. Derycke for example states, 'One day or another, all prostitutes aspire to a life away from prostitution, whatever they may say’ (my emphasis). ${ }^{15}$

AIDS prevention and community health groups are deeply critical of what they perceive as a moralistic and paternalistic attitude towards prostitutes, to whom all voice and agency is denied until they see the light and agree to be 'reintegrated'. ${ }^{16}$ They claim to give voice to prostitutes and to work in partnership with them to meet their needs. Cabiria takes this further, presenting prostitutes not only as agents, but as rational decisionmakers. The group’s annual report emphasises the agency of prostitutes, including migrants who choose to come and work in France: 
If the fact of prostituting may at first sight seem a submission to the system, from the perspective of the strategies of agents, one could consider that through prostitution these women make men pay directly and explicitly for what other women give freely or [charge for] indirectly in this same system of domination, thus gaining autonomy. ${ }^{17}$

Abolitionist discourse became so dominant during the Jospin government that its proponents could present it as non-ideological ${ }^{18}$ or above the abolition-regulation dichotomy. ${ }^{19}$ Abolitionist organisations formed a powerful lobby with effective access to policy makers and with the resources to fund conferences and publications. The UNESCO conference was supported by prominent public figures including leading light on the Republican left, founder of the Mouvement des Citoyens party and presidential candidate, Jean-Pierre Chevènement, and philosopher and academic, Sylviane Agacinski. The thirty-five signatories of a declaration in Le Nouvel Observateur that the body is not a commodity included prominent political figures François Hollande, Robert Hue and Dominique Voynet. Senator Dinah Derycke's report on prostitution for the Senate’s delegation for women's rights did not question the principle of abolition, but merely assessed the extent to which the state implemented this policy at the national and local level.

In direct opposition to the dominant state-sanctioned abolitionism, prostitutes' rights' advocates, community health associations and some feminists called for the removal of the stigma attached to prostitution and for the recognition of the rights of sex workers. They argued that the state's blinkered commitment to abolitionism ignored difficulties, dangers and the denial of rights faced by prostitutes in their daily lives and that their existence and needs must be recognised, that they should be seen as subjects and agents, not victims. The associations Act Up-Paris, PASTT, Cabiria and AIDES Paris-Ile-deFrance condemned the UNESCO conference, which, they argued, further stigmatised sex workers and denied them the right to use their own bodies. ${ }^{20}$ They argued that the sale of sexual services should not be confused with slavery and trafficking, and demanded that 
the government concentrate on improving the working conditions of sex workers and their access to health and social services.

Vigorous debate took place, artificially and unproductively polarised around victims or sex workers; abolition or prostitutes’ rights; violence or work. ${ }^{21}$ Feminists and the left were split. These debates are replicated throughout the world, and are expressed in the existence and activities of transnational organisations as well as in the divisions that arise in international arenas, such as UN negotiations. What is specific about the French case, however, is that France presents itself as the epitome of abolitionism and at the forefront of what it portrays as the Dutch-led drive towards decriminalisation.

By 2002, public debate on prostitution, whether in institutional politics, the media, the organisations that work with prostitutes or against prostitution, was starkly polarised. Relations between the two poles were hostile, there was little, if any, dialogue, and the policy solutions which seemed to follow from their arguments were incomplete: sex workers' rights advocates fought for better living and working conditions for those in prostitution, but did not challenge the circumstances which brought them there.

Abolitionists were caught in the contradictions of the term 'abolitionism', which can refer to the abolition of the state regulation of prostitutes or to the abolition of prostitution itself. They could not endorse any legislation that addressed prostitutes specifically, because this was reminiscent of the regulationist regime they oppose. One of the problems this produced was that they could not find a solution to the question of taxation. Prostitutes and pimps are currently liable for tax on their earnings from prostitution, according to the principle that all income is taxable, regardless of its source. Prostitutes who appear to be working independently are placed in the same category as professionals and non-commercial service providers. Those who are clearly working for a pimp are taxed as wage earners. The tax office has considerable powers of investigation and can estimate taxable earnings if no tax return is received. This estimate rarely takes into account the proportion of these earnings which is paid to the pimp, and few prostitutes identify their pimp to the tax office for obvious reasons. Abolitionists object to the current situation on the grounds that it appears to legitimise prostitution, to suggest that it 
is an occupation, and to place the state in the position of profiting from the prostitution of another, which is an offence (Article 225-5 of the penal code). The official recognition of prostitution in taxation policy contradicts the state's abolitionist position. However, if prostitutes were exempt from tax liability, this would mean that there would be specific laws which applied to them, and this is also contrary to the principle of abolitionism. It might even encourage prostitution and would make pimping even more lucrative, since pimps would not be discovered by the tax office in the course of investigations into the tax liability of prostitutes. ${ }^{22}$ The abolitionist goal of eradicating prostitution has as a direct and immediate consequence opposition to measures which would improve the health and safety of those in prostitution. The solution to unpleasant working conditions, they claim, is to leave prostitution, not to make it less unpleasant.

Sex workers' rights' advocates provide short-term services and solutions to everyday problems. Abolitionist organisations attempt to provide long-term solutions to prostitutes who seek an alternative. Although some individuals and organisations on the ground (for example the Amicale du Nid and the Bus des femmes) were working together across these ideological differences to enable people in prostitution to access health, social and legal services, it seemed that the (false) abolition-regulation dichotomy was preventing any possibility of fighting for a real and immediate improvement in the living and working conditions of prostitutes, as part of a long-term strategy to remove the conditions which enable prostitution as an institution to exist. A broader, inter-agency, preventative approach, called for by Derycke ${ }^{23}$ and Marcovich, ${ }^{24}$ amongst others, would require sustained political will if it were to be pursued. Any political will that may have existed prior to 2002 has been neutralised by the reframing of the 'problem' of prostitution as one of law and order. This severely curtails the possible policy responses.

Despite the irreconcilable dichotomies around which the debate was organised at this time, the central concern was what was best for prostitutes themselves. This is illustrated by the claims made by all parties that they spoke on behalf of/in the interests of/with prostitutes themselves, and that their opponents refused to give prostitutes voice and agency. ${ }^{25}$ Whether the ideal outcome was seen as their escape from prostitution or 
improved living and working conditions with access to full citizenship rights as prostitutes, this was the heart of the issue. There was never any question of penalising prostitutes, who were positioned either as victims or as workers. Nicolas Sarkozy's Domestic Security Bill, however, radically changed this, launching a war not on prostitution, but on prostitutes.

Even before Sarkozy had drafted his bill, mayors were beginning to respond to complaints by local residents about the presence of prostitutes in their neighbourhoods. In the summer of 2002, Françoise de Panafieu, UMP deputy for the $17^{\text {th }}$ arrondissement in Paris, led a high-profile campaign against the way in which prostitution lowers the tone of her neighbourhood and upsets its residents. There was particular concern about keeping prostitution out of the sight of children (and in particular, away from school entrances), always phrased to suggest that it is the sight of prostitutes which is a threat to children's moral development, not the sight of the local male clients.

Mayors (on the right and the left) passed bye-laws preventing prostitution in particular residential and business areas (initially in Strasbourg, Orléans, Aix-en-Provence and Metz). As the state's commitment to abolitionism prevented it from passing legislation aimed specifically at prostitutes, these mayors initially took pains to circumvent the restrictions by introducing traffic and parking bye-laws to drive prostitution out of certain areas. This meant that prostitutes were forced to leave well-lit busy streets and move into car parks, lay-bys and wasteland, where they work in far less safe conditions. However, with the rise of law and order discourse, in particular since the run-up to the 2002 presidential elections, an increasing number of local authorities have introduced more explicit bye-laws aimed at preventing prostitution in designated areas.

\section{The Domestic Security Bill}

Despite the positive reception of the Derycke report by Parliament, its conclusions were pushed into the background by a combination of factors: the Senator who wrote it retired on ill health; international and European measures demanded parliamentary debates on transnational organised crime, modern slavery and trafficking; and, in 2002, the 
Presidential and parliamentary elections brought to power a rightwing President and parliamentary majority, at the end of a campaign focused almost exclusively on law and order. Prostitution suddenly found itself redefined as a law and order issue.

The Domestic Security Bill was tabled in October 2002 by the Minister for the Interior, Nicolas Sarkozy, and brought into force in March 2003 after successful readings in both houses of Parliament. The bill was presented by Sarkozy as a welcome response to a widespread feeling of insecurity which dominates public concerns. It aimed to combat types of behaviour which are causing increasing concern and 'legitimate exasperation' amongst French citizens. ${ }^{26}$ These types of behaviour are soliciting, exploitation of begging, aggressive begging, occupying someone else's land and assembling in the entrance or the stairwell of blocks of flats. According to the government, clamping down on these activities would improve the quality of life and especially the feeling of security of the poorest members of society who are most likely to become the victims of crime. According to their critics, these proposals constitute an attack on the poor. ${ }^{27}$

The bill provoked petitions, demonstrations and calls for action by parties of the left, trade unions and associations concerned with human rights, poverty and social justice. They accused Sarkozy of exploiting the climate of insecurity and rejected the plans to criminalise beggars, prostitutes, travellers and young people, arguing that 'no-one chooses to be a beggar or a prostitute, to live in neighbourhoods with no facilities and no public services'. ${ }^{28}$ Claude Boucher from the Bus des femmes, a support service in Paris run by prostitutes and former prostitutes, insists that many women she meets work as prostitutes in order to preserve their dignity, since neither social security benefits nor the minimum wage are enough to live on. Treating them as criminals will make their lives more dangerous, she argues: 'This is a law against those who are excluded, against the most vulnerable. ${ }^{29}$

Sarkozy, however, claimed that the poor support a tougher stance on crime, that law and order is the main concern of the general public, and that $80 \%$ of people on the minimum wage approve of his bill. An Ipsos poll, cited by Le Figaro, demonstrated that the lower 
the income and education, the greater the support for the bill. Sarkozy claims that 'it is precisely for this forgotten France that the government has tabled this bill', and while his opponents argue that it is in place of a social policy, Sarkozy states that 'Creating public security is the first step in an effective social policy'. ${ }^{30}$

Three parts of the law are concerned specifically with prostitution: Article 18 which, firstly, criminalises soliciting and, secondly, makes it an offence for clients to pay for sex with a particularly vulnerable person; Article 28 which permits the removal of a visitor's permit from foreigners caught soliciting; and Article 29 which allows a foreign prostitute who brings charges against or who testifies against her pimp to remain in the country until the case has been heard, and, as a result of a government amendment during the debate in the Senate, to remain in the country permanently if the pimp or trafficker is convicted.

\section{Criminalisation of Soliciting}

Soliciting becomes a major offence (un délit as opposed to une contravention). This reclassification of soliciting means that it can now incur a prison sentence (6 months in the original, 2 months as the result of a successful amendment during the Parliamentary debates) as well as a more substantial fine than previously. It also means that suspected offenders can be held in custody for up to forty-eight hours. And this is one of the main justifications for the reclassification, because it allows the police to obtain information from them during their time in custody ${ }^{31}$ - in other words, it is intended to contribute to the fight against the exploitation of prostitution.

Secondly, the law reintroduces the notion of 'passive soliciting', which was removed from the New Penal Code in 1994 (interestingly by a rightwing majority). Before 1994, there was a distinction between active and passive soliciting, with passive soliciting defined as hanging around in the street in a way that was likely to encourage vice. The new Penal Code retained only the notion of active soliciting. Sarkozy, arguing that it was inconvenient for the police to have to obtain evidence of active soliciting, proposed the insertion of a new article in the Penal Code (Article 225-10-1) creating a serious offence 
of soliciting by any means including 'dress or posture.' The reference to 'dress' caused an outcry and was removed by a government amendment during the Senate debate. The version that was passed by the Senate refers to 'a posture, even passive'. ${ }^{32}$ Some newspapers argued that the introduction of passive soliciting as a major offence effectively makes street prostitution illegal. ${ }^{33}$ It opens up opportunities for police harassment, discrimination and arbitrary decision-making. For immigrant women, there are additional implications: if found guilty of soliciting, they can have their visitor's permit withdrawn and be deported.

Sarkozy justified the criminalisation of passive soliciting on the grounds that it protects prostitutes, and helps them to escape from the mafia networks which exploit them. ${ }^{34}$ Apart from being an unacceptable justification for arresting somebody, this is disingenuous, since Sarkozy knows that not all street prostitutes are mafia controlled. This demonstrated that prostitution is not the only issue targeted by this law. It is intimately connected with the control of immigration. Much of Sarkozy’s discourse suggests, often explicitly, that the real targets of his bill were foreign prostitutes. They are portrayed as a homogeneous group: they are all controlled by trafficking rings, are all victims of slavery, must therefore all be charged with passive soliciting, held in custody while the police obtain information about the trafficking rings, and then deported, in order to rescue them from their exploiters. There is no relative autonomy or lack of autonomy and no concern with the conditions under which foreign women enter the country and begin to work as prostitutes.

There have been many calls for measures aimed directly at trafficking rings, rather than claiming that arresting prostitutes will have significant impact on their activities. These calls have come from the Senate’s Law Commission, the Delegations for women's rights in the Senate and the National Assembly, and opposition members of both houses. Some changes have been made in response: trafficking has now been defined as an offence and penalties set, although this was at least partly a response to international and European requirements. Also, when Sarkozy addressed the National Assembly on the first day of 
the debate on his bill, he announced that the means for combating trafficking rings were to be doubled.

Article 29 states that temporary permission to remain in the country can be given to a foreigner who brings charges or gives evidence against a pimp. A government amendment passed by the Senate extends this to permanent permission when it leads to a conviction. But critics ask why it should be conditional on testimony, when the person concerned is recognised as a victim of trafficking. There are still contradictions here, which derive from the different objectives of the people concerned. Sarkozy’s aim was to remove foreign prostitutes from the country. In his preliminary statements in July 2002 (LOPSI), he made it clear that the targets of his prostitution policy were migrant women. But he has been forced to add some less punitive measures and to increase the possibilities for reintegration into French society for some victims of trafficking under certain conditions.

\section{The Construction of Prostitutes}

The public framing of prostitution as a form of violence towards women during the Jospin government was the result of action by women's policy agencies who, under pressure from feminist activists and in conjunction with a powerful abolitionist lobby, were able to influence the policy agenda and policy debates. This framing constructs prostitutes as women, and in the majority of cases they are, although the more striking gendered aspect of prostitution is the fact that pimps, traffickers and clients are overwhelmingly men. Sarkozy, however, has reconstructed prostitutes not as women victims of violence, but as one of a number of groups that threaten public safety.

In much of the current debate, prostitutes are divided into 'good' French prostitutes, who do not disturb the peace and 'bad' foreign prostitutes who undercut prices, offer unprotected sex, and work indiscreetly upsetting local residents. ${ }^{35}$ Sarkozy has tried to combine a construction of the prostitute as victim, which is currently popular and emotive, with the prostitute as criminal, who must be charged and expelled from the country (he focuses almost exclusively on foreign prostitutes). He talks about deportation 
as though he were doing them a favour - sending them home where they can resume their lives without degrading themselves: 'It's no big deal to send home someone who is the victim of violence inflicted by pimps in Paris or Deauville! Don't tell me that this is not doing them a good turn! Who would wish the situation in which these girls find themselves to persist? [...] It seems wise to escort girls who do not speak our language and who have just arrived in our country back to their country of origin in order to release them from the grasp of their pimps. It is a humanitarian duty!' ${ }^{36}$

There seems to be a broad consensus that the sexual trafficking of women is a violation of their human rights, especially when they are imprisoned by their pimps, their papers are confiscated, and they receive none of the money they have earned. All EU member states accept that women (and men and children) who have been trafficked are victims, although this status does not necessarily confer on them any rights. There is no such consensus, however, around the idea that prostitution itself is an inherent violation of human rights.

In stark contrast with Dinah Derycke just two years earlier, Janine Rozier, author of the report on the bill by the Senate's Delegation for women's rights, argued that the proposed legislation was in keeping with the abolitionist position which is the basis of France's international commitments. ${ }^{37}$ Part of the reason why she could do this is the malleability of the term 'abolition' which can mean either the eradication of prostitution or the abolition of regulations targeted at prostitutes. Derycke favoured the latter, although with the eventual disappearance of prostitution as a distant objective. Part of her understanding of abolitionism was that all prostitutes are by definition victims of a system of prostitution and must be helped to escape from it. This precludes the criminalisation of prostitutes. Rozier, on the other hand, stresses that 'increasing the penalties for people who enter prostitution is justified by the dual need to stop networks of pimps and to ensure public order. ${ }^{38}$ 


\section{Criminalising Clients}

The criminalisation of passive soliciting must surely draw attention to the fact that prostitutes are held solely responsible for the transaction with the client, who remains, in the eyes of the law, entirely innocent. Until March 2002, clients were completely absent from legislation on prostitution. Since then, they have been committing an offence if the prostitute is under $18 .^{39}$ The Domestic Security Law extends this provision to include clients of prostitutes who are particularly vulnerable, and included in this group are those who are pregnant or have a mental or physical illness or disability which is clear to the client. This in itself raises a number of issues, although they will not be discussed here. With these exceptions, then, standing on the street waiting for someone to pay them in exchange for sex becomes a serious offence. Stopping on the street and paying for sex, however, is a civil liberty. So who is disturbing the peace and upsetting the local residents? Why the prostitute and not the client? Is he merely an innocent victim of her active - or passive - temptations? And what does this tell us about men's responsibility for their sexual behaviour? Does it relegitimise the defence of the rapist that 'she was asking for it', especially in the original bill's explicit inclusion of the way the prostitute dresses as a sign of her responsibility for the transaction?

An amendment tabled by three Socialist deputies proposing either to fine clients of prostitution or to offer them a course to make them aware of their responsibility for their actions was rejected by the National Assembly. The Law Commission argued that this would not work. Sarkozy said that we should wait and see what happens as a result of the criminalisation of clients of underage and vulnerable prostitutes. ${ }^{40}$ There were also various calls on the left for information campaigns, education, and awareness-raising about the effects of prostitution, ${ }^{41}$ but none of this found its way into government policy.

Some clients of prostitution have been charged with soliciting and sexual exhibitionism, although these cases are rare and convictions even more so. It is interesting to note that middle class and professional men are reported to have moved away from street prostitution, the only form of prostitution affected by the new legislation, to other forms 
of commercial sex ${ }^{42}$, where they will not be affected by the possibility of prosecution for soliciting or sexual exhibitionism, or for using underage or vulnerable prostitutes, nor by any future attempts to criminalise clients directly.

\section{Conclusion}

Prostitutes do not seem to share the right to security that Sarkozy is so attached to. ${ }^{43}$ Despite his repeated assertions that this was a means of assuring the security of the poorest members of society who are, he argued, the most frequent victims of crime, it in fact creates new groups of criminals which have in common poverty and/or social exclusion. The left declared it 'a war on the poor, not on poverty. ${ }^{44}$ Criminalising prostitutes without doing anything to remove the underlying causes of prostitution (for example, poverty, systematic gender segregation and discrimination in the labour market, systemic male domination of women, and widely accepted beliefs about men's natural sexual urges) will make prostitutes’ living and working conditions even more dangerous and insecure. They will be forced to work in less safe areas; they will be even more reluctant to seek police help even when they are in serious physical danger; they will be inadequately protected from violent pimps; and foreign prostitutes will be at greater risk of deportation. The reintroduction of passive soliciting and its upgrading from minor to serious offence increases the likelihood of police focusing on women from particular ethnic groups.

International and EU-driven concern with reducing trafficking has exerted a growing influence on the way in which prostitution is perceived as a political issue, but there has been strong pressure from the influential abolitionist lobby to resist the trend towards focusing on trafficking and to try to maintain focus on prostitution itself. They draw on the 1949 UN Convention, which portrays prostitution and trafficking as inextricably linked, trafficking being an 'accompanying evil' of prostitution, not a discrete issue that can be addressed by separate measures. But this has not prevented an elision of 'prostitution' and 'the prostitution of foreign women', perceived as a homogeneous group, exploited by evil pimps, and both trafficked and forced. This has been ardently rejected by groups such as Cabiria, which claims that the portrayal of migrant women in 
prostitution as victims is exaggerated and misleading, and that this removes their autonomy and agency, and obscures the real problems they experience which are associated with the social stigma attached to prostitution, and with their lack of access to social and health care and to full citizenship rights. On the other hand, however, Cabiria stresses the autonomy and rational decision making of third world women migrating to western industrialised nations to such an extent that the possibility of any form of manipulation, oppression or abuse appears to be excluded. ${ }^{45}$

Sarkozy did not adopt a fully coherent position on prostitution; this is not what he set out to do. Instead, he aimed to satisfy voters concerned about the visible signs of prostitution that cause them anxiety. ${ }^{46}$ He intended to clean up the streets, and, in this respect, he has succeeded. The Paris police report a 40\% drop in the number of prostitutes on the streets. ${ }^{47}$ But in so doing, he has transformed the terms of the debate and redefined street prostitutes not as victims, but as criminals. The prostitution debate is now framed in terms of public nuisance and law and order, and is closely entwined with the control of immigration. It creates a narrow view of prostitution as taking place only on the streets, thus exonerating middle class men who have become consumers of other forms of commercial sex, rather than the clients of prostitution who, although not targeted explicitly by this law, have finally been recognised in public debate as participants in prostitution, in contrast to their somewhat surreal invisibility until now. 'Independent', 'traditional', 'French' prostitutes have also to a large extent survived the worst effects of the law, with reassurances from the ministerial office that it was never intended to affect them. The targets, then, are those who, paradoxically, are more likely to be perceived as victims than any other women in prostitution: migrant women who, in the government's eyes, if not in reality, have all been trafficked and are all being exploited, often viciously, by foreign pimps.

A preliminary study of the impact of the new legislation in Paris suggests that prostitution has not been reduced; it has simply moved to more isolated areas and more discreet hours (3-7am). ${ }^{48}$ The study suggests that this makes it more difficult for community health and prostitutes' rights groups to provide services and that it exposes prostitutes to greater 
risks of violence. It also reports a degradation in relations between French and foreign prostitutes, with increased evidence of racism. The newspapers report increased insecurity since the change in the law. In Toulouse and Lyon, there are reports of years of good relations built up with the police being destroyed overnight. ${ }^{49}$ There are some claims that young African and Slav girls are not being arrested, on the grounds that, as minors, they would have to be given accommodation and a visitor's permit. Blandine Grosjean writes, 'In March 2002, France nonetheless passed some of the most protective laws on minors and some of the most punitive on clients of minors. ${ }^{50}$ Judges are reluctant to convict for soliciting. Of the 230 cases brought by the police in Bordeaux, for example, fewer than ten have resulted in a conviction. The Syndicat de la Magistrature disputes the concept of passive soliciting as an offence, when prostitution is legal. ${ }^{51}$

During the parliamentary debates on the Domestic Security Bill, some of the measures from the modern slavery bill were incorporated into amendments in order to remove some of the harshest treatment of the victims of trafficking. What the debates reveal, however, is the continued inability to meet both the short-term and long term needs and interests of the diverse women who are currently working in prostitution in France.

\footnotetext{
${ }^{1}$ Foreign prostitutes are estimated by the Office central pour la répression des trafics d'êtres humains, OCRETH, to account for two thirds of the 15-20 000 prostitutes currently working in France, Le Monde, 11 July 2002.

2 The impact of the women's policy machinery in France and its effectiveness in improving women's rights and status has been studied in detail by Dorothy Stetson and Amy Mazur (eds.), Comparative State Feminisms, Thousand Oaks, London and New Delhi: Sage, 1995. See also Amy Mazur, Theorising Feminist Policy, Oxford and New York: Oxford University Press, 2002.

${ }^{3}$ Dinah Derycke, 'Rapport d'activité 2000: les politiques publiques et la prostitution’, Délégation du Sénat aux droits des femmes et à l'égalité des chances entre les hommes et les femmes', 31 January 2001, http://www.senat.fr/rap/r00-209/r00-209.html, consulted
} 17 October 2001. 
${ }^{4}$ For a full discussion of these debates, see Amy Mazur, 'Prostitute movements face elite apathy and gender-biased universalism in France', in Joyce Outshoorn (ed.), The Politics of Prostitution, Cambridge: Cambridge University Press, pp. 123-43.

${ }^{5}$ The Netherlands was the first country to recognise prostitution as sex work (in 1999), making the distinction between free and forced prostitution. See Joyce Outshoorn, 'Legalizing Prostitution as Sexual Service: the Case of the Netherlands', Copenhagen ECPR Joint Sessions Workshop 12, April 2000.

${ }^{6}$ Lin Lean Lim (ed.), The Sex Sector: The Economic and Social Bases of Prostitution in Southeast Asia, Geneva: International Labour Office, 1998.

${ }^{7}$ Such as the additional protocol to the Convention on Children's Rights on the sale and prostitution of children and on child pornography, passed by the UN on 25 May 2000 and signed by 69 states, including all the member states of the EU, and the Convention on Transnational Organised Crime with the additional protocol on trafficking, negotiated in Vienna and signed in December 2000 in Palermo.

${ }^{8}$ http://www.social.gouv.fr/femmes/actu/doss consulted 21 October 2001.

${ }^{9}$ Alain Vidalies, Rapport d’information no. 3459, déposé par la Mission d’information commune sur les diverses formes de l'esclavage moderne, 12 December 2001, www.assemblee-nationale.fr/rap-info/i3459.asp .

10 Joyce Outshoorn, 'Debating Prostitution in Parliament: A Feminist Analysis', European Journal of Women's Studies, Vol. 8, no. 4, November 2001, pp. 472-90.

${ }^{11}$ No. 1325, 23 April 1997.

${ }^{12}$ Cabiria, Annual Report 2000, http://perso.wanadoo.fr/cabiria/pagesinenglish, accessed November 2001, p. 2.

${ }^{13}$ UNESCO, Conference 'Peuple de l'Abîme: la prostitution aujourd'hui', 16 May 2000, www.fondationscelles.org, accessed 23 October 2000, pp. 5-6.

${ }^{14}$ Elizabeth Coquart and Philippe Huet, Le Livre noir de la prostitution, Paris: Albin Michel, 2000.

${ }^{15}$ Dinah Derycke, 'Rapport d’activité 2000’, op. cit., p. 26.

${ }^{16}$ See, for example, Lilian Mathieu, Mobilisations de prostituées, Paris: Belin, 2001, p. 24. 
${ }^{17}$ Cabiria, Annual Report 2000, op. cit., p. 4, English in original.

${ }^{18}$ For example, Malika Nor, La Prostitution, Paris: Le Cavalier Bleu, 2001.

${ }^{19}$ Dinah Derycke, 'Rapport d'activité 2000', op. cit.

${ }^{20}$ Act Up-Paris, PASTT, Cabiria, AIDES Paris-Ile-de-France, Press Release 16 May 2000, www.actupp.org/news/news , consulted 10 December 2001.

${ }^{21}$ For abolitionist arguments see, for example Elizabeth Coquart and Philippe Huet, Le Livre noir de la prostitution, op. cit.; UNESCO Conference 'Peuple de l’Abîme’ op. cit.; Malika Nor, La Prostitution, op. cit. For prostitutes’ rights arguments see Cabiria, Annual Report 2000, op. cit.; Lilian Mathieu, Mobilisations de prostituées, op. cit.; Claude Boucher, 'Le point de vue du Bus des femmes: Entretien’, ProChoix, no. 17, février-mars 2001, pp. 28-30.

22 Dinah Derycke, 'Rapport d’activité 2000’, op. cit., p. 35.

23 Ibid.

${ }^{24}$ Marcovich, Malka, 'Le système de la prostitution: une violence à l'encontre des femmes', http://www.social.gouv.fr/femmes/gd_doss/prostitution12prostitution.htm, 5 March 2002.

${ }^{25}$ UNESCO, Conference 'Peuple de l’Abîme', op. cit.; Elizabeth Coquart and Philippe Huet, Le Livre noir de la prostitution, op. cit.; Cabiria, Annual Report 2000, op. cit.; Lilian Mathieu, Mobilisations de prostituées, op. cit.; Marie-Victoire Louis, 'Pour une critique de la politique pro-prostitution de Cabiria’, August 2001, http://www.penelopes.org, consulted 12 October 2001.

${ }^{26}$ Nicolas Sarkozy, Exposé des motifs, Projet de loi pour la sécurité intérieure, No. 30, 2002-3, presented to the Senate 23 October 2002, www.senat.fr.

${ }^{27}$ Ligue des droits de l’Homme, Syndicat des Avocats de France, Syndicat de la Magistrature 'Lettre ouverte à Monsieur Sarkozy’, http://www.ldh-france.asso.fr/actu 29 October 2002.

${ }^{28}$ Ibid.

${ }^{29}$ Délégation de l'Assemblée nationale aux droits des femmes et à l'égalité des chances entre les hommes et les femmes, 'Compte rendu no. 2’, 15 October 2002, Présidence de 
Marie-Jo Zimmermann, www.assemblee_nationale.fr/12/cr-delf/02-03/c0203002.asp , accessed 28 October 2002.

${ }^{30}$ Le Monde, 23 October 2002.

${ }^{31}$ Clarisse Fabre and Philippe Le Coeur, 'Prostitution: Le Sénat veut compléter le projet Sarkozy’, Le Monde, www.lemonde.fr 31 October 2002.

${ }^{32}$ Compte rendu analytique officiel de la séance du 14 novembre 2002.

${ }^{33}$ Libération, 23 October 2002, Le Monde 23 October 2002.

${ }^{34}$ Le Monde, 23 October 2002.

${ }^{35}$ For example, Clarisse Fabre and Pascale Krémer, 'Plusieurs centaines de "personnes prostituées” se sont rassemblées à Paris contre le projet Sarkozy’, Le Monde, lemonde.fr, 6 November 2002; Le Monde, 16 January 2003.

${ }^{36}$ Nicolas Sarkozy, Compte rendu analytique officiel de la séance du 14 novembre 2002, http://www.senat.fr/

37 Janine Rozier, Rapport d'information fait au nom de la délégation du Sénat aux droits des femmes sur le projet de loi no. 30 (2002-3) pour la sécurité intérieure. Rapport no. 34, 29 October 2002, http://www.senat.fr/

38 ibid.

${ }^{39}$ Loi no. 2002-305 du 4 mars 2002, Legifrance, www.legifrance.gouv.fr.

40 1ère séance du mardi 21 janvier 2003.

${ }^{41}$ For example, Ségolène Royal and Martine Lignières-Cassou, 1ère séance du mardi 21 janvier 2003.

42 Daniel Welzer-Lang, 'L’échangisme: une multisexualité commerciale à forte domination masculine’, in Michel Bozon (ed.) Sociétés contemporaines, 41/42, 2001, pp. 111-31.

43 http://www.premier-ministre.gouv.fr, 24 October 2002.

${ }^{44}$ About thirty parties and associations signed a call for opposition to this 'war on the poor'. These included the CGT, ATTAC, CADAC, CNDF, LCR, LDH, MRAP, PCF and the PS. They stated that 'This bill instigates a Republic where poverty is a crime', http://france.attac.org/ , consulted 22 October 2002. See also President of the Ligue des droits de l’Homme, Michel Tubiana, in Le Monde, 23 October 2002. 
${ }^{45}$ Cabiria, Annual Report 2000, op. cit.

${ }^{46}$ Nicolas Sarkozy, Exposé des motifs, op. cit.

${ }^{47}$ Sylvia Zappi, 'La Mairie de Paris doute d'une baisse spectaculaire de la prostitution', Le Monde, 15 January 2004.

${ }^{48}$ A study by Janine Mossuz-Lavau and Marie-Elisabeth Handman, commissioned by the Mairie de Paris, submitted 27 November 2003, and widely reported in the press, for example, Sylvia Zappi, 'La Mairie de Paris doute d'une baisse spectaculaire de la prostitution', Le Monde, 15 January 2004; Blandine Grosjean, 'Prostitution: contre enquête de la Mairie de Paris, Libération, 14 January 2004, p. 18.

${ }^{49}$ Blandine Grosjean, 'Des filles de joie bien à la peine’, Libération, 13 June 2003.

${ }^{50}$ Blandine Grosjean, 'Prostitution: contre enquête de la Mairie de Paris, Libération, 14 January 2004, p. 18.

${ }^{51}$ Hippolyte Colas, 'A Bordeaux, la justice distanciée par la police', L'Humanité, 17

December 2003; Marie-Christine Tabet, 'Justice: La loi Sarkozy du 18 mars sur la prostitution', Le Figaro, 6 May 2003. 